\title{
The productivity and spring barley grain quality depending on mineral fertilizer systems
}

\author{
N. V. Sanina \\ Volga Scientific Research Institute of Selection and Seed-Growing named after P.N. Konstantinov - Branch of the Federal State \\ Budgetary Institution of Science Samara Federal Research Scientific Center of Russian Academy of Sciences, Kinel, Samara region, \\ 446442, Russia
}

\begin{abstract}
The research purpose is to study the effect of systematic application of various doses of mineral fertilizers on productivity, grain quality, value of spring barley productivity elements, determine an optimal doses of nitrogen, phosphorus and potassium in the arid conditions of the Middle Volga region. Improving nutrition with the use of fertilizers contributed to an increase in productivity values. The average yield was $0.18-0.76 \mathrm{t} / \mathrm{ha}$. The use of maximum doses of nitrogen, phosphorus and potassium did not increase productivity in arid conditions. Nitrogen plays a leading role in increasing barley productivity. The agronomic effectiveness of fertilizers depended on the doses of active substances. An increase was $2.1-5.8 \mathrm{~kg}$ of barley grain per $1 \mathrm{~kg}$ of active substances. The most stable increase was observed when applying $\mathrm{N}_{60} \mathrm{P}_{0-60} \mathrm{~K}_{0-30}$. Rational doses are as follows: nitrogen $60-90 \mathrm{~kg}$ a.e./ha when applying $\mathrm{P}_{60} \mathrm{~K}_{30}$, phosphorus $30-60 \mathrm{~kg}$ a.e./ha when applying $\mathrm{N}_{60} \mathrm{~K}_{30}$, potassium $30 \mathrm{~kg}$ a.e./ha when applying $\mathrm{N}_{60} \mathrm{P}_{60}$. The best option is $\mathrm{N}_{60} \mathrm{P}_{0-60} \mathrm{~K}_{0-30}$.
\end{abstract}

\section{Introduction}

Spring barley is one of the most important food, feed and industrial crops. The solution to the problem of increasing and stabilizing grain production depends on the nutrition of plants.

At the same time, a significant part of the crop is formed due to soil resources $[1,2]$. However, over the past 35 years in the Volga region, the frequency of droughts has increased to $70 \%$, the share of springsummer and persistent droughts has increased [3-5]. The use of fertilizers allows plants to spend soil moisture more economically, reducing the stress of the climate, and increasing plant productivity [6,7].

Due to the insufficient use of fertilizers, a significant part of soils of the Volga and Samara regions lacks basic elements of plant nutrition $[8,9]$. To preserve and replenish soil resources and improve plant nutrition, it is necessary to use fertilizers.

However, even Pryanishnikov D.N. emphasized that with a sharp lack of water, fertilizers have no effect, and under certain conditions they have a harmful effect on the growth and development of plants [10].

According to VNIIA, it has been established that in the European part of the Russian Federation the efficiency of fertilizers decreases when moving to the southeast and south due to the continental climate $[1,2]$.

The aim of the research is to study the effect of systematic application of various doses of mineral fertilizers on productivity, grain quality, elements of productivity of spring barley, and to determine optimal doses of nitrogen, phosphorus and potassium in the arid conditions of the Middle Volga region.

\section{Materials and methods}

Experimental data on the spring barley yield, productivity elements and grain quality were obtained in 2000-2013 on the long-term stationary crop rotation experimental fields of the Volga RI named after P.N. Konstantinov.

The soil is a typical medium humus, medium heavy loamy chernozem. In 2008, the nutrient content was as follows: humus $-4.6-7.2 \%, \mathrm{pH}_{\mathrm{KCl}}-5.5-6.29$, mobile phosphorus according to Chirikov $-10.6-35.0 \mathrm{mg} / 100 \mathrm{~g}$, exchange potassium according to Chirikov $14.4-29.0 \mathrm{mg} / 100 \mathrm{~g}$. The predecessor was spring wheat. The cultivation technology is generally accepted for spring barley in this area.

The experiment scheme: 1. No fertilizers, control; 2. $\mathrm{N}_{0} \mathrm{P}_{60} \mathrm{~K}_{30} ; \quad$ 3. $\mathrm{N}_{30} \mathrm{P}_{60} \mathrm{~K}_{30} ; \quad$ 4. $\mathrm{N}_{60} \mathrm{P}_{60} \mathrm{~K}_{30} ; \quad$ 5. $\mathrm{N}_{90} \mathrm{P}_{60} \mathrm{~K}_{30}$; 6. $\mathrm{N}_{120} \mathrm{P}_{60} \mathrm{~K}_{30} ;$ 7. $\mathrm{N}_{60} \mathrm{P}_{0} \mathrm{~K}_{30} ;$ 8. $\mathrm{N}_{60} \mathrm{P}_{30} \mathrm{~K}_{30} ;$ 9. $\mathrm{N}_{60} \mathrm{P}_{90} \mathrm{~K}_{30}$; 10. $\mathrm{N}_{60} \mathrm{P}_{30} \mathrm{~K}_{0} ; 11 . \mathrm{N}_{60} \mathrm{P}_{60} \mathrm{~K}_{60}$.

These options made up 3 systems of mineral fertilizers: with increasing doses of nitrogen (options 1-6), phosphorus (options $1,7,8,4,9$ ) and potassium nutrition (options 1, 10, 4, 11).

As mineral fertilizers, we used ammonium nitrate, nitrogen phosphate, double granular superphosphate, potassium chloride.

The studies were carried out in accordance with generally accepted methods based on the Methodology 
of state variety testing of agricultural crops and methodological developments of the Volga RI [11-13]. Statistical processing of the data was carried out according to the method by B.A. Dospekhov and methodological developments of the Volga RI.

\section{Results}

Research years varied in hydrothermal conditions, but arid periods of different duration and intensity were observed annually. The most arid years were 2010 and 2013 with long-term steady drought, which occurred during the growing season. In June-July, the hydrothermal coefficient was 0.04 and 0.37 , respectively, the productivity was $0.51-0.78 \mathrm{t} / \mathrm{ha}$, and the maximum yield increase did not exceed 0.24 t/ha. A drought of lesser intensity took place in 2005, the SCC amounted to 0.55 , and the yield was $0.92-1.47 \mathrm{t} / \mathrm{ha}$. The most favorable years were 2001, 2003 and 2007, when the dry periods were short. During these years, the productivity was $2.05-3.44 \mathrm{t} / \mathrm{ha}$. The remaining years were moderately arid, making it possible to obtain a yield of $0.97-2.83$ t/ha.

A correlation analysis was carried out between the yield, the yield increase and hydrothermal indicators at various intervals of the vegetation period. It showed that the hydrothermal indices affect the yield during the whole period of barley vegetation.

However, the greatest correlation between the increase in yield and the main meteorological indicators was observed during three decades from the third decade of May to the second decade of June (Table 1). According to the calculation, a significant negative effect of temperatures on the yield increase was observed in options 3, 4 and 10. The lack of precipitation affected the yield in options 3-7 and 9-11, a low hydrothermal coefficient was obtained in options $3-5$ and $10-11$.

Table 1. The relationship between yield and yield increase with the main hydrothermal indicators in the period from the 3 rd decade of May to the second decade of June. The significant correlation coefficient is $r>0.577$

\begin{tabular}{|c|c|c|c|c|c|c|}
\hline \multirow{2}{*}{ 苛 } & \multicolumn{3}{|c|}{$\begin{array}{c}\text { The correlation coefficient } \\
\text { of productivity and }\end{array}$} & \multicolumn{3}{|c|}{$\begin{array}{l}\text { The correlation coefficient } \\
\text { of the increase in yield and }\end{array}$} \\
\hline & $\begin{array}{c}\text { air } \\
\text { temper } \\
\text { ature }\end{array}$ & $\begin{array}{c}\text { precipi } \\
\text { tation }\end{array}$ & $\begin{array}{l}\text { hydrother } \\
\text { mal } \\
\text { coefficient }\end{array}$ & $\begin{array}{c}\text { air } \\
\text { temper } \\
\text { ature }\end{array}$ & $\begin{array}{c}\text { precipit } \\
\text { ation }\end{array}$ & $\begin{array}{c}\text { hydrother } \\
\text { mal } \\
\text { coefficient }\end{array}$ \\
\hline 1 & -0.621 & 0.462 & 0.609 & - & - & - \\
\hline 2 & -0.620 & 0.469 & 0.608 & -0.319 & 0.259 & 0.311 \\
\hline 3 & -0.704 & 0.560 & 0.690 & -0.696 & 0.618 & 0.681 \\
\hline 4 & -0.738 & 0.673 & 0.767 & -0.682 & 0.768 & 0.759 \\
\hline 5 & -0.680 & 0.677 & 0.739 & -0.508 & 0.685 & 0.628 \\
\hline 6 & -0.659 & 0.648 & 0.706 & -0.419 & 0.595 & 0.518 \\
\hline 7 & -0.631 & 0.620 & 0.689 & -0.364 & 0.593 & 0.507 \\
\hline 8 & -0.580 & 0.587 & 0.651 & -0.312 & 0.540 & 0.470 \\
\hline 9 & -0.607 & 0.620 & 0.684 & -0.407 & 0.603 & 0.559 \\
\hline 10 & -0.695 & 0.654 & 0.743 & -0.580 & 0.732 & 0.704 \\
\hline 11 & -0.687 & 0.634 & 0.721 & -0.575 & 0.661 & 0.654 \\
\hline
\end{tabular}

The value of spring barley productivity depended on the use of mineral fertilizers (Table 2).

Nitrogen plays a leading role in increasing the productivity of grain crops, including barley [14]. At the same time, barley uses 34-45\% nitrogen fertilizer [15]. The application of phosphorus and potassium fertilizers at a dose of 60 and $30 \mathrm{~kg}$ a.a./ha did not increase the barley yield. The use of nitrogen at a dose of $30-120 \mathrm{~kg}$ a.e./ha against the background of $\mathrm{P}_{60} \mathrm{~K}_{30}$ increased the productivity by $0.45-0.76 \mathrm{t} / \mathrm{ha}$.

At the same time, a consistent increase in barley productivity by $32-50 \%$ was observed when applying nitrogen at a dose of 30-60 kg ae/ha. A further increase in the dose of nitrogen to $90-120 \mathrm{~kg}$ ae/ ha did not increase the yield due to the arid conditions of the Volga region.

Thus, the use of nitrogen fertilizers at doses of 60 $120 \mathrm{~kg}$ ae/ha against the background of $\mathrm{P}_{60} \mathrm{~K}_{30}$ increases the productivity. Increasing doses of nitrogen in options 3-6 increased the barley yield by $0.27-0.57 \mathrm{t} / \mathrm{ha}$ (19-37 \%) compared to $\mathrm{P}_{60} \mathrm{~K}_{30}$. The "decaying nature" of high doses of mineral fertilizers for crops is also characteristic of other zones of the Russian Federation [16].

Table 2. Indicators of barley productivity elements. Average for 2000-2013 NDS $=0.21 \mathrm{t} / \mathrm{ha}$

\begin{tabular}{|c|c|c|c|c|c|c|c|}
\hline ڤే & : & 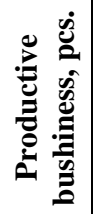 & 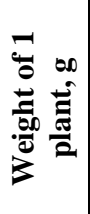 & 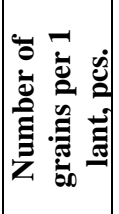 & 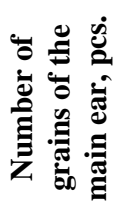 & 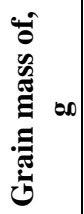 & 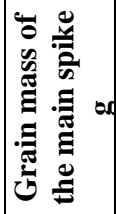 \\
\hline 1 & 1.41 & 2.0 & 2.87 & 28.4 & 17.4 & 1.29 & 0.80 \\
\hline 2 & 1.59 & 2.2 & 3.41 & 33.7 & 18.0 & 1.51 & 0.83 \\
\hline 3 & 1.86 & 2.4 & 3.71 & 35.1 & 18.4 & 1.61 & 0.86 \\
\hline 4 & 2.11 & 2.6 & 4.03 & 39.0 & 18.6 & 1.77 & 0.88 \\
\hline 5 & 2.17 & 2.6 & 3.97 & 42.0 & 19.1 & 1.78 & 0.90 \\
\hline 6 & 2.13 & 2.8 & 4.32 & 40.7 & 19.9 & 1.87 & 0.87 \\
\hline 7 & 1.92 & 2.4 & 3.65 & 37.1 & 18.9 & 1.64 & 0.87 \\
\hline 8 & 2.10 & 2.5 & 3.86 & 37.1 & 18.5 & 1.68 & 0.86 \\
\hline 9 & 2.15 & 2.7 & 4.28 & 40.4 & 18.7 & 1.86 & 0.87 \\
\hline 10 & 1.98 & 2.6 & 4.05 & 37.1 & 18.7 & 1.77 & 0.87 \\
\hline 11 & 2.09 & 2.4 & 3.76 & 37.3 & 18.8 & 1.65 & 0.86 \\
\hline
\end{tabular}

The use of phosphorus fertilizers against the background of $\mathrm{N}_{60} \mathrm{~K}_{30}$ increase the yield by $0.69-0.74$ t/ha (49-53\%) compared to the control and by $0.18-0.23 \mathrm{t} / \mathrm{ha}$ (9-12\%) compared to the background. An increase in the dose of phosphorus from 30 to $90 \mathrm{~kg}$ a.e./ha was not accompanied by a significant increase in the grain yield. This is due to the fact that phosphorus fertilizers are less soluble and mobile than nitrogen and potash fertilizers, react more strongly to the deterioration of the hydrothermal regime of soils, although they increase the resistance of plants to drought $[1,5,8,14]$.

Potash fertilizers did not increase the barley yield due to the sufficient amount of potassium in the soil. The optimal dose of potassium against the background of $\mathrm{N}_{60} \mathrm{P}_{60}$ was $30 \mathrm{~kg}$ a.e. ha with a yield increase of $0.7 \mathrm{t} / \mathrm{ha}$ (50\%).

In 2001, 2004, 2006 and 2008, the fertilizers applied were efficient: in options 4-11, yield increases amounted to $0.92-1.52$ tha, which exceeded the control one by $41-154 \%$.

The maximum increase was observed using 
fertilizers in options 4-6, 8, 9, 11.

An increase in the barley grain yield is due to an increase in the values of plant productivity elements (Table 2). Improving nutrition led to the development of productive shoots with $22.2-2.8$ pcs. in options $2-11$, the better development of plants, an increase in the weight of vegetative and generative organs. In options $2-11$, the plant weight increased by $19-50 \%$, the grain weight increased by $17-45 \%$, the number of grains increased by $19-48 \%$.

The growth was due to an increase in side shoots. In options 2-11, the weight of grain of the main spike increased by $4-13 \%$, and the weight of grain from the side shoots - by $38-100 \%$. The number of grains in the main spike increased by $3-14 \%$, from the side shoots by $43-108 \%$. The contribution of side shoots increased from $38 \%$ in the control option to $55 \%$ in options with fertilizers.

The highest indices of the structural elements were observed when applying nitrogen at doses of $60-120 \mathrm{~kg}$ a.e./ha and phosphorus at doses of $60-90 \mathrm{~kg}$ a.e./ha. The use of potash fertilizers did not change productivity elements.

Changes in the nutrient regime of the soil also affect quality indicators for barley grain (Table 3 ).

Table 3. Grain quality indicators. Average for 2000-2013

\begin{tabular}{|c|c|c|c|c|}
\hline Option & $\begin{array}{c}\text { Protein } \\
\text { content, \% }\end{array}$ & $\begin{array}{c}\text { Protein } \\
\text { yield, kg/ha }\end{array}$ & $\begin{array}{c}\text { Mass of } \\
\mathbf{1 0 0 0} \text { seeds, }\end{array}$ & $\begin{array}{c}\text { Grain } \\
\text { nature, g/l }\end{array}$ \\
\hline 1 & 13.1 & 185 & 43.2 & 625 \\
\hline 2 & 13.1 & 208 & 43.8 & 633 \\
\hline 3 & 13.6 & 253 & 44.0 & 634 \\
\hline 4 & 14.4 & 304 & 43.5 & 634 \\
\hline 5 & 15.1 & 327 & 43.7 & 631 \\
\hline 6 & 15.5 & 330 & 43.3 & 630 \\
\hline 7 & 14.8 & 284 & 43.9 & 629 \\
\hline 8 & 14.6 & 307 & 44.3 & 631 \\
\hline 9 & 14.7 & 316 & 43.9 & 627 \\
\hline 10 & 14.5 & 287 & 43.7 & 629 \\
\hline 11 & 14.6 & 305 & 43.9 & 629 \\
\hline
\end{tabular}

The protein content in the control option averaged $13.1 \%$. An increase in this indicator by $0.5-2.4 \%$ was observed when applying nitrogen fertilizers against the background of $\mathrm{P}_{60} \mathrm{~K}_{30}$, and the highest values were obtained when applying nitrogen at doses of $90-120 \mathrm{~kg}$ a.e./ha $-15.1-15.5 \%$.

An increase in the yield and protein content led to an increase in the yield per unit area by $12-78 \%$. The maximum increase was observed in options 5 and 6 (77-78 \%) with a nitrogen dose of 90 and $120 \mathrm{~kg}$ a.e./ha.

The values of the weight of 1000 seeds and the nature of grain exceeded the control ones by $0.1-1.1 \mathrm{~g}$ and 2-9 g/l, respectively, but in most cases they did not change. The highest values of these indicators were observed in option 3 ; in options 4 and 8 , an excess was observed for one indicator.

The agronomic evaluation of the effectiveness of fertilizers showed that the yield payment was $2.1-5.8 \mathrm{~kg} / \mathrm{kg}$ and depended on the doses of active fertilizer substances (Table 4).
The maximum yield payment of $5.7-5.8 \mathrm{~kg} / \mathrm{kg}$ was observed in options 7 and 8 with a total content of active substances of 90 and $120 \mathrm{~kg} / \mathrm{ha}$. In this case, the dose of nitrogen was $60 \mathrm{~kg}$ a.e./ha, potassium - $30 \mathrm{~kg}$ a.e./ha. Phosphorus was absent or its dose was $30 \mathrm{~kg}$ a.e./ha. In options 4, 5, 9 and 10 , the payment was $4.1-4.8 \mathrm{~kg}$ of grain per $1 \mathrm{~kg}$ of fertilizer with a total amount of active substances of $120-180 \mathrm{~kg} / \mathrm{ha}$. High doses of active ingredients in options 6 and 11 corresponded to lower payment values.

Nitrogen plays a leading. The agronomic efficiency of this element was highest. Payment depending on its dose was $4.5-8.9 \mathrm{~kg} / \mathrm{kg}$ against the background of $\mathrm{P}_{60} \mathrm{~K}_{30}$, its maximum efficiency was at doses of 30 and $60 \mathrm{~kg} / \mathrm{ha}$. Increasing the dose of nitrogen to 60 and 90 $\mathrm{kg} / \mathrm{ha}$ reduced the agronomic efficiency to 6.4 and 4.5 $\mathrm{kg} / \mathrm{kg}$, respectively. Without nitrogen (option 2), the efficiency of phosphorus-potassium fertilizers was minimal, payment was $2.1 \mathrm{~kg} / \mathrm{kg}$ with a statistically unreliable increase in the yield.

In the fertilizing system with increasing doses of phosphorus against the background of $\mathrm{N}_{60} \mathrm{~K}_{30}$, the effectiveness of this element decreased with increasing doses of phosphorus, payment of $1 \mathrm{~kg}$ of active substance decreased from $6.0 \mathrm{~kg} / \mathrm{kg}$ in option 8 to 2.6 $\mathrm{kg} / \mathrm{kg}$ in option 9 .

The lowest agronomic efficiency was observed when using the highest dose of potassium $60 \mathrm{~kg} / \mathrm{ha}$ against the background of $\mathrm{N}_{60} \mathrm{P}_{60}$ : the yield for this element was $1.9 \mathrm{~kg} / \mathrm{kg}$. While at a dose of $30 \mathrm{~kg} / \mathrm{ha}$, the payment was $4.4 \mathrm{~kg} / \mathrm{kg}$, and when using a complex of nitrogenphosphorus fertilizers (option 10), this value was $4.8 \mathrm{~kg} / \mathrm{kg}$.

Lower crop payment values corresponded to higher doses of active substances. This is due to the fact that in arid conditions, an increase in the barley yield with increasing doses of fertilizers was not proportional.

The optimal payment was observed when using $\mathrm{N}_{60} \mathrm{P}_{0.60} \mathrm{~K}_{0}$ 30.

Table 4. Agronomic performance indicators of mineral fertilizer systems.

\begin{tabular}{|c|c|c|c|}
\hline Option & $\begin{array}{c}\text { The yield increase } \\
\text { from the total } \\
\text { number of active } \\
\text { substances of } \\
\text { fertilizers, kg }\end{array}$ & $\begin{array}{c}\text { The total } \\
\text { number of } \\
\text { active } \\
\text { substances, } \\
\text { kg }\end{array}$ & $\begin{array}{c}\text { Payment of } \\
\text { fertilizers } \\
\text { by crop, } \\
\text { kg/kg }\end{array}$ \\
\hline 2 & 187 & 90 & 2.1 \\
\hline 3 & 455 & 120 & 3.8 \\
\hline 4 & 704 & 150 & 4.7 \\
\hline 5 & 761 & 180 & 4.2 \\
\hline 6 & 726 & 210 & 3.5 \\
\hline 7 & 513 & 90 & 5.7 \\
\hline 8 & 692 & 120 & 5.8 \\
\hline 9 & 745 & 180 & 4.1 \\
\hline 10 & 571 & 120 & 4.8 \\
\hline 11 & 682 & 180 & 3.8 \\
\hline
\end{tabular}

\section{Conclusion}

The systematic application of mineral fertilizers in 2000-2013 increased the yield up to $54 \%$. 
The leading role belongs to nitrogen. The maximum size and stability were obtained using fertilizers $\mathrm{N}_{60-120} \mathrm{P}_{30-90} \mathrm{~K}_{0-60}$. However, increased doses of mineral fertilizers did not provide significant yield increases compared with the $\mathrm{N}_{60} \mathrm{P}_{60} \mathrm{~K}_{30}$ option. To obtain high productivity, the optimal doses were as follows: nitrogen 60-90 kg a.e./ha against the background of $\mathrm{P}_{60} \mathrm{~K}_{30}$, phosphorus $30-60 \mathrm{~kg}$ a.e./ha against the background of $\mathrm{N}_{60} \mathrm{~K}_{30}$, potassium $30 \mathrm{~kg}$ a.e./ha against the background of $\mathrm{N}_{60} \mathrm{P}_{60}$.

The correlation between the yield and the yield increase with main hydrothermal indicators from the third decade of May to the second decade of June was revealed.

Strengthening the nutritional regime of plants increased the productive bushiness of barley plants, enhanced the development of plants, and increased such indicators as the grain weight, the number of grains per plant, and the plant weight. An increase in these indicators was due to an increase in the contribution of side shoots, which increase from $38 \%$ in the control option to $55 \%$ in the fertilized ones. The highest indices of the structural elements were observed when applying nitrogen at doses of $60-120 \mathrm{~kg}$ a.e./ha and phosphorus at doses of 60-90 kg a.e./ha.

An increase in the content of crude protein by $0.5-2.4 \%$ was due to nitrogen fertilizers against the background of $\mathrm{P}_{60} \mathrm{~K}_{30}$, and the highest values were obtained for doses of nitrogen of $90-120 \mathrm{~kg}$ a.e./ha. The content of crude protein increased by $12-78 \%$ with the largest increase when using doses of nitrogen of 90 and $120 \mathrm{~kg}$ a.e/ha.

The weight of 1000 seeds and the nature of grain were at the control level.

The agronomic effectiveness of fertilizers varied. The payment in crop increases was $2.1-5.8 \mathrm{~kg}$ per $1 \mathrm{~kg}$ of active substances. The payment values depended on the doses of active substances. The maximum value was $5.7-5.8 \mathrm{~kg} / \mathrm{kg}$ with a nitrogen dose of $60 \mathrm{~kg}$ a.e. $/ \mathrm{ha}$, potassium - $30 \mathrm{~kg}$ a.e./ha, with a minimum phosphorus dose of $30 \mathrm{~kg}$ a.e./ha or in its absence. The most effective active ingredient was nitrogen, the payment reached

$8.6-8.9 \mathrm{~kg} / \mathrm{kg}$ at doses of 30 and $60 \mathrm{~kg} / \mathrm{ha}$. Without this element, the effectiveness of phosphorus-potassium fertilizers was minimal $-2.1 \mathrm{~kg} / \mathrm{kg}$. Low agronomic efficiency of potassium is due to its sufficient content in the soil. The most stable payment was observed when using $\mathrm{N}_{60} \mathrm{P}_{0-60} \mathrm{~K}_{0-30}$.

Thus, having analyzed the indicators of productivity and grain quality, it can be concluded that in the systems of mineral fertilizers under arid conditions, rational doses were as follows: nitrogen $60-90 \mathrm{~kg}$ a.e./ha against the background of $\mathrm{P}_{60} \mathrm{~K}_{30}$, phosphorus $30-60 \mathrm{~kg}$ a.e./ha against the background of $\mathrm{N}_{60} \mathrm{~K}_{30}$, potassium $30 \mathrm{~kg}$ a a.e./ha against the background of $\mathrm{N}_{60} \mathrm{P}_{60}$. The optimal option was $\mathrm{N}_{60} \mathrm{P}_{60} \mathrm{~K}_{30}$.

The use of scientifically based and balanced doses of mineral fertilizers can increase the productivity of spring barley and improve soil fertility.

\section{References}

1. V.G. Sychev, S.A. Shafran, Agrochemical properties of soils and the effectiveness of mineral fertilizers (VNIIA, Moscow, 2013), 296 p.

2. S.A. Shafran, The influence of soil type and content of mobile phosphates on the effectiveness of phosphorus fertilizers, Agrochem. 3, 26-33 (2015)

3. A.V. Rumyantsev, V.V. Glukhovtsev, Scientific support of agricultural production stably productive and high-quality varieties of crops, Grain Econ. of Russ. 1, 5-9 (2012)

4. A.I. Pryanishnikov, I.V. Savchenko, A.I. Shabaev, The development of the scientific foundations of adaptive crop production in the Volga region, Agrar. Bull. of the South-East 1-2, 4-7 (2015)

5. N.G. Levitskaya, O.V. Shatalova, G.F. Ivanova, Droughts in the Volga region and their impact on grain production, Agrar. Bull. of the South-East 3-4, 71-74 (2010)

6. A.A. Zhuchenko, Possibilities of launching the Russian agro-industrial complex in the 21st century, Agrar. Bull. of the South-East 1, 6-11 (2009)

7. V.D. Pannikov, V.G. Mineev, Soil, climate, fertilizer and crop (Agropromizdat, Moscow, 1987), $512 \mathrm{p}$.

8. S.V. Obushchenko, V.V. Gnedenko, Analysis of soil fertility in the Samara region, Int. J. of Appl. and Fundam. Res. 4, 90-95 (2015)

9. S.V. Obushchenko, V.V. Gnedenko, The current state of soil fertility in the Samara region in 2016, Int. J. of Appl. and Fundam. Res. 6, 521-525 (2016)

10. D.N. Pryanishnikov, Selected Works, vol. 1 (Kolos, Moscow, 1965), $767 \mathrm{p}$.

11. Methods of state testing of crops (1971), $239 \mathrm{p}$.

12. V.V. Glukhovtsev, S.N. Zudilin, V.G. Kirichenko, Fundamentals of scientific research in agronomy, Course of lectures (State Agricultural Academy, Samara, 2008), $291 \mathrm{p}$.

13. V.V. Glukhovtsev, V.G. Kirichenko, S.N. Zudilin, Workshop on the basics of scientific research in agronomy (Kolos, Moscow, 2006), 240 p.

14. S.A. Shafran, E.S. Koseicheva, The productivity of spring barley and payback of nitrogen fertilizers depending on the content of nutrients in the main types of soils in Russia, Agrochem. 3, 11-22 (2016)

15. N.Ya. Shmyreva, A.A. Zavalin, O.A. Sokolov, Streams and nitrogen balance of fertilizer and soil nitrogen under crop rotation on eroded sod-podzolic soil (studies with 15N), Fertility 3, 50-53 (2019)

16. A.V. Pasynkov, E.V. Svetlakova, N.V. Kotelnikova, V.D. Abashev, E.N. Pasynkova, G.G. Sadakova, S.A. Balandina, G.I. Dunyasheva, N.V. Rubleva, M.S. Tatarinova, The effect of prolonged use of mineral fertilizers on the fertility of sod-podzolic soil, crop rotation and grain quality, Agrochem. 10, 3847 (2016) 